\title{
WACANA TEOLOGIS KONTRA DEMOKRASI PANCASILA: ANALISIS SOSIO-PRAGMATIS TERHADAP AL-QUR'AN TARJAMAH TAFSIRIYAH MUHAMMAD THALIB
}

\author{
Mohamad Sobirin \\ Universitas Islam Negeri Walisongo Semarang \\ mohamadsobirin@walisongo.ac.id
}

\begin{abstract}
The Al-Qur'an Tarjamah Tafsiriyah, which is initiated by Muhammad Talib as a correction to the Al-Qur'an Tarjamah Kementerian Agama which was considered as a source of radicalization, has found its paradox in the Qur'anic translation regarding the relation between Islam and state. This paper intends to answer two questions: what is the strategy of Muhammad Thalib in translating verses containing the keywords of täghüt, tabkim, uli al-amr and awliya ? and how relevant is the translation to the context of Indonesian Pancasila and democracy? By using socio-pragmatic theory, this paper argues that the ideology of counter-Pancasila democracy has lied in the Al-Qur'an Tarjamah Tafsiriyah. It obviously appears in the texts of translation that Thalib attempt to fight for the formalization of Sharia as a state positive law. Muhammad Thalib, for example, more often interpreted the word tăghüt in the Qur'an as heretical rules. These rules are contextually interpreted as thoughts, concepts, and ideologies that lead people to go astray from the way of God, including democracy, pluralism, secularism, liberalism, and Pancasila.
\end{abstract}

Keywords: Al-Qur'an Tarjamah Tafsiriyah, Muhammad Thalib, Democracy of Pancasila.

\begin{abstract}
Abstrak: Al-Qur'an Tarjamah Tafsiriyah yang diinisiasi Muhammad Thalib sebagai koreksi atas Al-Qur'an Tarjamah Kementerian Agama yang dinilai menjadi sumber radikalisasi, justru ditemukan adanya paradoks dalam penerjemahan Alquran yang berkaitan dengan relasi agama dan negara dalam konteks demokrasi Pancasila. Tulisan ini dimaksudkan untuk menjawab dua pertanyaan: bagaimana strategi penerjemahan tafsiriyah Muhammad Thalib terhadap ayat-ayat yang memuat kata täghüt, taḅkim, uli al-amr dan awliya $\bar{a}$ ? dan bagaimana relevansi penerjemahan tafsiriyah tersebut dalam konteks wacana demokrasi Pancasila di Indonesia? Dengan menggunakan teori sosiopragmatik, tulisan ini berargumen bahwa di dalam Al-Qur'an Tarjamah Tafsiriyah bersemayam ideologi kontra demokrasi Pancasila. Hal itu bisa
\end{abstract}


dibuktikan dari upaya Thalib dalam memperjuangkan formalisasi Syariat ke dalam hukum positif negara yang tertuang dalam teks-teks penerjemahannya. Muhammad Thalib, misalnya, lebih sering mengartikan kata täghüt dalam Alquran sebagai 'aturan-aturan sesat'. Aturan-aturan ini secara kontekstual dimaknai sebagai pemikiran, konsep hidup, dan ideologi yang menyesatkan manusia dari jalan Allah, termasuk di dalamnya yaitu demokrasi, pluralisme, sekulerisme, liberalisme, dan Pancasila.

Kata Kunci: Al-Qur'an Tarjamah Tafsiriyah, Muhammad Thalib, Demokrasi Pancasila.

\section{Pendahuluan}

Demokrasi sering diidentifikasi sebagai sistem pemerintahan yang lahir dari dunia Barat. Asal-usul sistem pemerintahan modern tersebut telah dijadikan sebagai salah satu alasan bagi sebagian kalangan umat Islam untuk menolak sistem pemerintahan demokrasi. Penolakan terhadap sistem demokrasi juga dibangun di atas argumentasi yang menyatakan bahwa demokrasi tidak kompatibel dengan Islam. Menurut kalangan ini, Islam telah menyediakan sistem pemerintahan yang sempurna sebagaimana tertuang dalam Alquran dan diteladankan oleh Nabi beserta para al-khulafä' al-räshidün.

Dalam konteks Indonesia, kelompok yang menilai demokrasi sebagai sistem pemerintahan yang tidak kompatibel dengan Islam di atas telah melakukan serangkaian gerakan propaganda yang dimaksudkan untuk menggantikan sistem konstitusional Indonesia yang berpijak pada demokrasi Pancasila dengan tawaran al-kbiläfah alislämiyah yang mereka klaim sebagai sistem pemerintahan Islam. Di antara strategi gerakan yang mereka tempuh adalah melalui wacana keagamaan yang mereka produksi dan distribusikan ke tengah publik Muslim Indonesia. Salah satu wacana tersebut mengetengahkan isu hubungan Islam dengan negara dalam konteks demokrasi. Muhammad Thalib dan organisasi yang dia pimpin, Majelis Mujahidin Indonesia (MMI), termasuk pihak yang memiliki konsen terhadap wacana ini.

Muhammad Thalib melalui Majelis Mujahidin Indonesia (MMI) telah memproduksi wacana hubungan Islam dan negara dalam konteks demokrasi Pancasila melalui Al-Qur'an Tarjamah Tafsiriyah. Di dalam karya tersebut ayat-ayat yang sering dirujuk dalam membahas isu demokrasi dalam Islam dan hubungan Islam dengan negara diterjemahkan secara tafsiriyah, sehingga menarik potensi perbedaan 
secara metodis dan konten dengan penerjemahan yang diinisiasi oleh Kementerian Agama. ${ }^{1}$

Wacana Muhammad Thalib dan MMI yang mengetengahkan isu relasi agama dan negara dalam bingkai demokrasi Pancasila, tidak hanya bisa ditemukan dalam penerjemahan ayat-ayat yang mengandung kosa kata kunci seperti täghüt, tahkim, uli al-amr, dan awliy $\bar{a}$ ' beserta derivasinya, namun juga dalam artikel-artikel yang dipublikasikan melalui media resmi mereka, seperti Risalah Mujabidin yang dalam beberapa edisi mengangkat isu ini.

Oleh karena itu, tulisan ini dimaksudkan untuk mengungkap: pertama, bagaimana strategi penerjemahan tafsiriyah Muhammad Thalib terhadap ayat-ayat yang memuat kata täghüt, taḅkim, uli al-amr, dan awliy a' beserta derivasinya? Kedua, bagaimana relevansi penerjemahan tafsiriyah terhadap ayat-ayat tersebut dengan konteks wacana demokrasi Pancasila di Indonesia? Karena Al-Qur'an Tarjamah Tafsiriyah juga mengambil sikap korektif terhadap penerjemahan Alquran Kementerian Agama RI dan

Setidaknya ada tiga alasan mendasar mengapa diskursus ini penting untuk dikaji. Pertama, ayat-ayat yang memuat kata-kata țäghut, taḥkim, uli al-amr, dan awliy à' beserta derivasinya memiliki jumlah yang terbilang banyak dan memiliki latar historis. ${ }^{2}$ Kosa kata täghüt misalnya, dimuat dalam enam ayat yang berbeda; QS. al-Baqarah [2]: 257, ${ }^{3}$ QS. al-Nisā' [4]: 60 ${ }^{4}$ dan 76, ${ }^{5}$ QS. al-Mā'idah [5]: 60, ${ }^{6}$ QS. al-Nahl [16]: 36, dan al-Zumar [39]: 17. ${ }^{8}$ Sedangkan ayat yang memuat kosa kata taḥkim, yang artinya berhukum dengan selain hukum Allah,

\footnotetext{
1 Muhammad Thalib mengklaim bahwa Terjemah Al-Qur'an Kementerian Agama memuat 3.229 jumlah kesalahan, sehingga mendorong dirinya untuk memberikan koreksi terhadap kesalahan tersebut melalui karya Tarjamah Tafsiriyah. Muhammad Thalib, Al-Qur'an Tarjamah Tafsiriyab: Memahami Makna Al-Qur'an Lebih Mudah, Tepat dan Mencerabkan (Yogyakarta: Ma'had An-Nabawy, 2011), 1052.

2 Muhammad Fu'ād 'Abd al-Bāqī, Mu'jam Mufahras li Alfäă al-Qur'ān, (Beirut: Dār alFikr, 1992), 533-536.

3 Täghüt diartikan "setan”. Thalib, Al-Qur'an Tarjamah Tafsiriyah, 51.

4 Täghüt diartikan "aturan-aturan sesat". Ibid., 103.

5 Täghüt diartikan "setan". Ibid., 105.

6 Tăghüt diartikan "berhala". Ibid., 137.

7 Tăghüt diartikan "segala kesyirikan". Ibid., 322.

8 Tăghüt diartikan “setan”. Ibid., 583.
} 
terdapat pada QS. al-Mā'idah [5]: 44, ${ }^{9} 45,{ }^{10}$ dan $47 .{ }^{11}$ Adapun ayat Alquran yang menyebut kosa kata yang bermakna perintah taat kepada uli al-amr terdapat pada QS. al-Nisā' [4]: 59. ${ }^{12}$ Tiga kosa kata dalam ayat-ayat tersebut belum termasuk dalam bentuk derivasinya; $f i l$ mädli, fi'l mudäri', amr, jam', dan yang bersambung dengan zamir serta beberapa bentuk lainnya.

Kedua, penerjemahan terhadap ayat-ayat yang memut kosa kata täghüt, taḩkim, ulì al-amr, dan awliy à' beserta derivasinya merefleksikan pandangan Muhammad Thalib sekaligus MMI dalam menyoal relasi Islam dan negara dalam konteks demokrasi Pancasila. Penerjemahan ini memiliki konteks wacana karena dihadirkan dengan metode tarjamah tafsirȳjah. Secara pragmatik, penerjemahan ini juga memiliki hubungan erat dengan wacana yang dia produksi dalam bentuk artikel di media yang dipublikasikan oleh Majelis Muhahidin Indonesia.

Ketiga, beberapa peneliti yang telah mengkaji Al-Qur'an Tarjamah Tafsiriyah, umumnya fokus pada aspek metode penerjemahan seperti Rizqa Ahmadi ${ }^{13}$ dan Muchlis M. Hanafi ${ }^{14}$. Selebihnya, ada juga yang menelaah aspek kandungan makna dan ideologi dalam Al-Qur'an Tarjamah Tafsiriyah, seperti Marjan Fadil ${ }^{15}$ dan Moch. Nur Ichwan ${ }^{16}$.

\footnotetext{
9 "Siapa saja yang tidak mau menetapkan dan melaksanakan hukum sesuai Syariat yang Allah turunkan kepada Nabi-Nya, mereka itulah orang-orang kafir”. Ibid., 134. 10 "Siapa saja yang tidak mau menetapkan qisās, hukuman setimpal dalam perkara pembunuhan dan penganiayaan syariat yang Allah turunkan kepada Nabi-Nya, maka mereka itulah orang-orang zhalim". Ibid.

11 "Siapa saja yang tidak mau melaksanakan hukum sesuai Syariat yang Allah turunkan kepada Nabi-Nya, mereka itulah orang-orang yang faasiq, durhaka kepada Allah". Ibid.

12 "Wahai kaum mukmin, taatlah kalian kepada Allah dan taatlah kepada Rasul-Nya, serta para pemimpin yang menegakkan Syariat Islam dari golongan kalian.” Ibid., 103.

13 Rizqa Ahmadi, "Model Terjemahan Al-Qur'an Tafsiriyah Ustad Muhammad Thalib," dalam Center of Middle Eastern Studies: Jurnal Studi Timur Tengah, vol. 8, no. 1 (2015), 57-69.

14 Muchlis M. Hanafi, "Problematika Terjemahan Al-Qur'an," dalam Subuf Jurnal Pengkajian Al-Qur'an dan Budaya, vol. 4. no. 2 (2011), 169-195.

15 Marjan Fadil, "Nalar Eksklusif Penafsiran Al-Qur'an Studi Terjemah Depag dan Tarjamah Tafsiriyah," dalam Journal of Qur'an and Hadith Studies, vol. 5, no. 2 (2016), 123-150.

16 Moch. Nur Ichwan, "Negara, Kitab Suci, dan Politik: Terjemahan Resmi alQur'an di Indonesia," dalam Henri Chambert-Loir (ed.), Sadur: Sejarah Terjemahan di Indonesia dan Malaysia (Jakarta: Kepustakaan Populer Gramedia, Ecole francaise d'Extreme-Orient, dan Pusat Bahasa Universitas Padjadjaran, 2009).
} 
Secara khusus penelitian mereka belum menyentuh hubungan penerjemahan beberapa kata kunci yang disebutkan di atas dengan wacana demokrasi Pancasila.

\section{Analisis Sosio-Pragmatik}

Penelitian ini menggunakan teori Sosio-Pragmatik sebagai pendekatan dalam proses analisis. Penggunaan teori ini dikarenakan keberadaan penerjemahan kata-kata kunci di atas dalam Al-Qur'an Tarjamah Tafsiriyah menyiratkan adanya unsur konteks pragmatik di dalamnya. Unsur pragmatik bisa dilihat dari tujuan dihadirkannya karya sebagai koreksi terhadap Alquran terjemahan Kementerian Agama, sekaligus fungsi bahasa yang dipilih dalam penerjemahan yang diformat untuk mengkoreksi penerjemahan ayat-ayat Alquran dalam Alquran terjemahan Kementerian Agama.

Jika ditinjau dengan menggunakan teori fungsi bahasa Van Ek dan Trim, keberadaan Al-Qur'an Tarjamah Tafsiriyah lebih dominan fungsi membangun wacana dibandingkan lima fungsi lainnya, yaitu untuk menyampaikan dan mencari informasi faktual, mengekspresikan dan merubah sikap, meminta pihak lain berbuat sesuatu, sosialisasi dan meningkatkan komunikasi yang efektif. ${ }^{17}$ Pragmatik dalam hal ini memiliki keterkaitan erat dengan fungsi bahasa untuk membangun wacana.

Setidaknya, terdapat tujuh pengertian pragmatik dalam pandangan Levinson. Salah satu tujuh definisi tersebut menyebutkan bahwa analisis pragmatik dilakukan dengan mengukur kesesuaian antara kalimat yang diungkapkan dengan konteksnya. ${ }^{18}$ Oleh karena itu, menurut Michael Canale, Sosio-Pragmatik memiliki pengertian sebagai ketepatan makna, yaitu sejauh mana fungsi komunikasi, sikap, dan gagasan tertentu dinilai berkesesuaian dengan situasi yang berlaku. Analisis semacam ini, berhubungan erat dengan aspek sosiologi ${ }^{19}$. Jenny Thomas dalam artikelnya Cross Cultural Failure menarik kesimpulan bahwa dalam perspektif Sosio-Pragmatik, kegagalan

\footnotetext{
17 JA.Van Ek dan J. L. M. Trim, Threshold 1990 (Cambridge: Cambridge University Press. 1991).

18 Stephent C. Levinson, Pragmatics (Cambridge: Cambridge Univercity Press, 1983), 21-24.

19 Michael Canale, "From Communicative Competence to Communicative Language Pedagogy," dalam Richard, Jack C. dan Schmidt E. (eds), Language and Communication (London: Longman, 1983).
} 
berkaitan erat dengan perilaku bahasa yang dilatarbelakangi oleh pengetahuan lintas budaya (cross culture). ${ }^{20}$

Pengetahuan lintas budaya dalam penerjemahan ini penting, karena menurut Larson, perubahan dalam penerjemahan seharusnya hanya diberlakukan pada aspek bentuknya saja, sedangkan makna dalam bahasa sumber yang akan ditransfer ke bahasa sasaran haruslah konstan atau tidak berubah. ${ }^{21}$ Pandangan Larson ini disetujui oleh Newmark yang menyatakan bahwa maksud si pengarang teks dalam bahasa sumber harus tersampaikan oleh si penerjemah dalam bahasa sasaran. ${ }^{22}$

Oleh karena itu, dalam pandangan Nida, untuk mewujudkan penerjemahan yang mempertahankan ketepatan makna dan terhindar dari kegagalan Sosio-Pragmatik, maka proses penerjemahan harus melalui tiga tahap; analisis, pengalihan, dan penyusunan ulang. ${ }^{23}$ Sementara itu, Newmark menawarkan enam strategi untuk mengatasi problem penerjemahan yang berkaitan dengan pengetahuan lintas budaya, yaitu: transferensi (loan words atau borrowing), naturalisasi, calque, modulasi, padanan budaya, dan transposisi. ${ }^{24}$ Analisis penelitian ini menggunakan perspektif strategi ini untuk melihat strategi penerjemahan yang digunakan oleh Al-Qur'an Tarjamah Tafsiriyah dalam menerjemahkan kosa kata täghbüt, taḥkim, uli al-amr, dan awliya dalam Alquran yang memiliki konteks Sosio-Pragmatik.

\section{Muhammad Thalib, Majelis Mujahidin Indonesia dan Al- Qur'an Tarjamah Tafsiriyah}

Nama Muhammad Thalib dikenal oleh masyarakat Indonesia dalam konteks yang tidak bisa dipisahkan dari dua hal: Majelis Mujahidin Indonesia dan Al-Qur'an Tarjamah Tafsiriyah. Meskipun para peneliti sebelum studi ini banyak meneyebut bahwa Muhammad Thalib lahir dalam tradisi keagamaan Nahdlatul Ulama, tepatnya di Gresik, menimba pengetahuan Islam di Bangil, kemudian menerjemahkan kitab-kitab berbahasa Arab, menulis banyak artikel

\footnotetext{
20 Jenny Thomas, "Cross Cultural Failure," dalam Applied Linguistics, vol. 4, no. 2 (1983), 91-112.

${ }^{21}$ Mildred L. Larson, Meaning Based Translation: A guide to Cross Language Equivalence (USA : University Press of America, 1998), 3.

22 Peter Newmark, A Text Book of Translation (Great Britain: Prentice Hall inc, 1988).

${ }^{23}$ Eugene Albert Nida, Context in Translating (Netherland: John Benjamins, 2001), 33.

${ }^{24}$ Newmark, A Text Book, 45-47.
} 
dan buku, dan membuat kurikulum Bahasa Arab yang bahkan dijadikan sebagai kurikulum nasional MI dan MTs tahun 1979-1985 oleh Kementerian Agama RI, namun reputasi tersebut bukanlah faktor yang menjadikan banyak masyarakat Indonesia mengenal dirinya.

Dalam pandangan penulis, keberadaan Muhammad Thalib yang dikenal khalayak muslim Indonesia lebih dilatarbelakangi oleh peran strukturalnya di dalam organisasi yang sebelumnya dipimpin oleh Abu Bakar Ba'asyir, yaitu Majelis Mujahidin Indonesia. Kasus terorisme yang menjerat Ba'asyir dan identitas organisasi ini dalam menyuarakan dan mengupayakan tegaknya khiläfah di Indonesia, serta kerap kali mengritik sistem Demokrasi dan dasar Negara Pancasila yang dianut di Indonesia, ${ }^{25}$ telah menjadikan organisasi ini mengemuka di tengah perhatian publik. Posisi Muhammad Thalib sebagai Amir 'Amm (20082013) dalam organisasi yang memiliki visi tegaknya Syariat Islam di dalam kehidupan umat Islam ini telah menarik dirinya untuk turut dijadikan sorotan oleh banyak pihak.

Sorotan publik terhadap Muhammad Thalib semakin menguat seiring dengan karyanya berupa tarjamah Alquran, terlebih karya itu ia klaim sebagai kritik sekaligus koreksi terhadap Alquran tarjamah Kementerian Agama RI. Al-Qur'an Tarjamah Tafsiriyah karya Muhammad Thalib ini telah terbit dalam 2 versi: 1) Edisi Spesial alQur'an Tarjamah Tafsiriyah dan Koreksi Tarjamah Harfiyah alQur'an Kemenag RI ukuran 21 x $14 \mathrm{~cm}$, xlvi + 614 halaman yang dicetak sebanyak 10.000 eksemplar; ${ }^{26}$ 2) Edisi Istimewa al-Qur'an Tarjamah Tafsiriyah dan Koreksi Tarjamah Harfiyah al-Qur'an Kemenag RI ukuran $25 \times 17 \mathrm{~cm}$, xlvi +714 halaman juga 10.000 eksemplar.

Karya yang dilucurkan pada 31 Oktober 2011 di atas, selain didorong oleh keinginan Muhammad Thalib untuk menghadirkan terjemah Alquran yang mudah difahami oleh muslim Indonesia yang umumnya tidak memahami bahasa Arab serta menyampaikan pesanpesan dalam ayat Alquran, ${ }^{27}$ juga dimotivasi oleh pandangan yang dia anut mengenai keharusan menerjemahkan Alquran dengan metode

\footnotetext{
25 Pandangan yang demikian salah satunya tampak dalam buku terbitan resmi Majlis Mujahidin yang berjudul Panduan Daurah Syar'iyah untuk Penegakan Syari'ah Islam (Yogyakarta: Markaz Majlis Mujahidin Pusat, 2010).

${ }^{26}$ Edisi Spesial ini yang penulis gunakan sebagai objek kajian dalam penyusunan tulisan ini.

27 Thalib, Al-Qur'an Tarjamab Tafsiriyah, iii.
} 
tafsiryah dan keharaman menerjemahkan Al-Qur'an dengan metode harfiyah. ${ }^{28}$ Thalib menilai bahwa Al-Qur'an dan Terjemabnya karya Kementerian Agama RI menggunakan metode ḥarfiyah. Bahkan dia mengklaim bahwa penggunaan metode literalis yang dilakukan oleh Kementerian Agama RI merupakan pemicu radikalisme di Indonesia. Oleh karena itu, ia memandang perlu ada koreksi terhadap terjemahan itu. Dalam penuturannya, bahwa setelah penelitian khusus selama 10 tahun terhadap Al-Qur'an dan Terjemahnya terbitan Kemenag RI yang sejak 1965 telah mengalami revisi secara bertahap mulai tahun 1989, 1998, 2002, hingga 2010, dia menyatakan bahwa ada banyak kesalahan penerjemahan di dalamnya. ${ }^{29}$ Hasil penelitiannya melaporkan bahwa terdapat 3140 kesalahan terjemahan dalam Al-Qur'an Terjemah Kementerian Agama RI. ${ }^{30}$

Dasar pemikiran lain yang melatarbelakangi Muhammad Thalib untuk membuat karya terjemahan Alquran dengan metode tafsiriyahadalah pandangan Thalib yang meyakini bahwa padangan radikal umat Islam disebabkan oleh kesalahan mereka dalam memahami ayat-ayat Alquran. Sementara itu, kesalahan memahami ayat Alquran di kalangan umat Islam disebabkan kesalahan mereka dalam memahami terjemahan ayat-ayat Alquran. Sehingga kesalahan terjemah berdampak pada kesalahan memahami teks Alquran. ${ }^{31}$ Terjemah ḩarfiyyah Alquran yang dilakukan oleh Kemenag RI dianggap sebagai tindakan mengubah ayat Alquran dari maksud sebenarnya, bahkan dapat menyesatkan. ${ }^{32}$

\footnotetext{
28 Muhammad Thalib, Koreksi Tarjamah Harfiyah Al-Qur'an Kemenag RI: Tinjauan Aqidah, Syar'iyah, Mu'amalah, Iqtishadiyah (Yogyakarta: Yayasan Islam Ahlu Shuffah \& Pusat Studi Islam an-Nabawi, 2011), 9.

${ }^{29}$ Ibid., 11.

30 Jumlah ini berbeda dengan yang tertera pada website mereka www.alqurantafsiriyah.blogspot.com. Dalam website tersebut tercantum sebanyak 3229 ayat yang dinilainya salah terjemahan dalam Al-Qur'an dan Terjemahnya terbitan Kemenag RI.

31 Thalib, Koreksi Tarjamah Harfiyah, 11.

32 Ibid., 10.
} 


\section{Analisis Komparatif Strategi Penerjemahan antara Al-Qur'an Tarjamah Tafsiriyah dan Al-Qur'an Terjemah Kementerian Agama}

\section{Kata Tāghūt dan Derivasinya}

Pertama, kata täghüt dalam QS. al-Baqarah [2]: 257 dan QS. alZumar [39]: 17 diterjemahkan dengan "setan" baik dalam Al-Qur'an Tarjamah Tafsiriyah" maupun Al-Qur'an Terjemah Kementerian Agama. ${ }^{34}$ Mengacu pada kategori strategi penerjemahan yang ada, maka keduanya menempuh strategi semantik. Artinya menggunakan salah satu makna kata täghüt dalam bahasa sumber (Arab) ke dalam bahasa sasaran. Kata täghüt diterjemahkan "setan" bisa dirujuk pada salah satu keterangan Ibn Jarīr al-Ṭabarī dalam tafsirnya. ${ }^{35}$ Demikian juga dalam kamus Lisān al-'Arab, bagian huruf ta' (b), dalam bentuk kata kerja tagha (طنى), kata täghät juga diartikan salah satunya sebagai setan. ${ }^{36}$

Kedua, pada QS. Al-Nisā' [4]: 60, Al-Qur'an Tarjamah Tafsiriyah menerjemahkan kata täghüt secara berbeda dengan sumber asli penafsiran terhadap kata tersebut. Di sana, täghüt diartikan sebagai aturan-aturan sesat. ${ }^{37}$ Artinya, strategi yang ditempuh dalam penerjemahan kata ini adalah strategi modulasi, karena menerjemahkan sesuatu yang abstrak menjadi kongkrit. Sementara itu, Al-Qur'an Tarjamah Kementerian Agama menempuh strategi transferensi, karena kata tāghüt tetap diartikan dengan täghüt. ${ }^{38}$ Terjemahan ini menggunakan istilah dalam bahasa sumber ke dalam bahasa sasaran.

Ketiga, pada QS. al-Nisā' [4]: 76, Al-Qur'an Tarjamah Tafsiriyah menerjemahkan kata täghüt secara berbeda dengan sumber asli penafsiran terhadap kata tersebut. Täghüt diartikan sebagai setan. ${ }^{39}$ Dengan demikian, strategi yang ditempuh dalam penerjemahan kata ini adalah strategi calque, karena meminjam istilah untuk kolokasi yang umum atau frasa yang dikenal dalam bahasa sumber (فتجاوز قدره عدا

\footnotetext{
33 Thalib, Al-Qur'an Tarjamah Tafsiriyah, 51, 583.

34 Departemen Agama RI, Al-Qur'an dan Terjemahnya (Bandung: CV. Penerbit Diponegoro, 2008), 43, 460.

35 Abū Ja'far Muhammad b. Jarīr b. Yazīd b. Kathīr b. Ghālib al-Ṭabarī, Jāmi` alBayān fì Ta'mūl al-Qur'ān, vol. 3 (Beirut: Dār al-Kitāb, 1992), 21.

${ }^{36}$ Muhammad b. Manẓūr, Lisān al-'Arab, vol. 15 (Kairo: Dār Miṣrīyah li al-Ta’līf wa al-Tarjamah, 1982), 9.

37 Tagghüt diartikan "aturan-aturan sesat". Thalib, Al-Qur'an Tarjamah Tafsiriyah, 103.

38 Täghüt diartikan “Taghut”. Departemen Agama RI, Al-Qur'an dan Terjemahnya, 88.

39 Täghüt diartikan "setan”. Thalib, Al-Qur'an Tarjamah Tafsiriyah, 105.
} 
حد). Sementara itu, Al-Qur'an Tarjamah Kementerian Agama menempuh strategi transferensi, karena kata täghbüt tetap diartikan dengan täghüt. ${ }^{40}$

Keempat, pada QS. al-Mā'idah [5]: 60, Al-Qur'an Tarjamah Tafsiriyah menerjemahkan kata täghüt diartikan sebagai berhala. ${ }^{41}$ Ini berarti bahwa strategi yang ditempuh dalam penerjemahan kata ini adalah strategi modulasi, karena menerjemahkan sesuatu yang abstrak menjadi kongkrit. Sementara itu, Al-Qur'an Tarjamah Kementerian Agama menempuh strategi transferensi, karena kata täghüt tetap diartikan dengan täghüt. ${ }^{42}$

Kelima, pada QS. Al-Naḥl [16]: 36, Al-Qur'an Tarjamah Tafsiriyah menerjemahkan kata täghüt secara berbeda dengan sumber asli penafsiran terhadap kata tersebut. tăghüt diartikan sebagai kesyirikan. ${ }^{43}$ Artinya, strategi yang ditempuh dalam penerjemahan kata ini adalah strategi calque, karena meminjam istilah untuk kolokasi yang umum atau frasa yang dikenal dalam bahasa sumber الله على طغيان ذي كل) (دونه (دونه من فعبد. Sementara itu, Al-Qur'an Tarjamah Kemenag menempuh strategi transferensi, karena kata țäghüt tetap diartikan dengan täghüt. ${ }^{44}$ Terjemahan ini menggunakan istilah dalam bahasa sumber ke dalam bahasa sasaran.

\section{Kata Tahkim dan Derivasinya}

Pertama, penerjemahan tahkim dalam QS. al-Māiidah [5]: 44 versi Al-Qur'an Tarjamah Tafsiriyah yang tertulis "menetapkan dan melaksanakan hukum sesuai syariat yang Allah turunkan kepada NabiNya" ${ }^{\text {"45 }}$ menunjukkan strategi transposisi dengan merubah susunan dari verba menjadi nomina, dan strategi sosio-pragmatik dengan memberikan tambahan "syariat Allah". Sedangkan, penerjemahan yang ditulis dalam Al-Qur'an Terjemah Kementerian Agama mengartikan

\footnotetext{
40 Tăghüt diartikan “Ṭāghūt”. Departemen Agama RI, Al-Qur'an dan Terjemahnya., 90.

41 Täghüt diartikan "berhala”. Thalib, Al-Qur'an Tarjamah Tafsiriyah, 137.

42 Täghüt diartikan "taghut”. Departemen Agama RI, Al-Qur'an dan Terjemahnya, 118.

43 Täghüt diartikan "segala kesyirikan." Thalib, Al-Qur'an Tarjamah Tafsiriyah, 322.

44 Täghüt diartikan "taghut.” Departemen Agama RI, Al-Qur'an dan Terjemahnya, 271.

45 "Siapa saja yang tidak mau menetapkan dan melaksanakan hukum sesuai Syariat yang Allah turunkan kepada Nabi-Nya, mereka itulah orang-orang kafir." Thalib, Al-Qur'an Tarjamah Tafsiriyah, 134.
} 
ayat tabkim itu secara literal sesuai bunyi teks Arab dan struktur kalimatnya. ${ }^{46}$

Kedua, penerjemahan tạ̣kim dalam QS. al-Mā’idah [5]: 45 versi Al-Qur'an Tarjamah Tafsiriyah tertulis "menetapkan kisas, hukuman setimpal dalam perkara pembunuhan dan penganiayaan sesuai syariat yang Allah turunkan kepada Nabi-Nya"47 menunjukkan strategi transposisi dengan merubah susunan dari verba menjadi nomina, dan Sosio-Pragmatik dengan memberikan tambahan "qișass, hukuman setimpal dalam perkara pembunuhan dan penganiayaan sesuai syariat, dan kepada Nabi-Nya". Sedangkan, penerjemahan yang dituliskan oleh Al-Qur'an Terjemah Kementerian Agama, kata tahkim diterjemahkan secara literal sesuai bunyi teks Arab dan struktur kalimatnya. ${ }^{48}$

Ketiga, penerjemahan tạ̣kìm dalam QS. al-Mă’idah [5]: 47 versi Al-Qur'an Tarjamah Tafsiriyah yang tertulis "melaksanakan hukum sesuai syariat Allah turunkan kepada Nabi-Nya,"49 menunjukkan strategi literal sesuai bunyi teks Arab dan struktur kalimatnya. Sedangkan, penerjemahan yang dituliskan oleh Al-Qur'an Terjemah Kementerian Agama mengartikan ayat tahkim itu dengan strategi transposisi dengan memberikan sinonim kata hukum berupa "memutuskan perkara", dan Sosio-Pragmatik dengan memberikan tambahan catatan kaki nomor 420, yaitu:

"orang yang tidak memutuskan perkara menurut hukum Allah, ada tiga macam: a. karena benci dan ingkarnya kepada hukum Allah, orang yang semacam ini kafir (surah Al-Maa'idah ayat 44). b. karena menurut hawa nafsu dan merugikan orang lain dinamakan zalim (surah Al-Maa'idah ayat 45). c. karena Fasik sebagaimana ditunjuk oleh ayat 47 surah ini')..$^{50}$

\footnotetext{
46 "Barangsiapa tidak memutuskan dengan apa yang diturunkan Allah, maka mereka itulah orang-orang kafir.” Departemen Agama RI, Al-Qur'an dan Terjemahnya,115.

47 "Siapa saja yang tidak mau menetapkan Qisas, hukuman setimpal dalam perkara pembunuhan dan penganiayaan yariat yang Allah turunkan kepada Nabi-Nya, maka mereka itulah orang-orang zhalim.” Thalib, Al-Qur'an Tarjamah Tafsiriyah, 134.

48 "Barangsiapa tidak memutuskan menurut apa yang diturunkan Allah, maka mereka itulah orang-orang zalim." Departemen Agama RI, Al-Qur'an dan Terjemahnya, 115.

49 "Siapa saja yang tidak mau melaksanakan hukum sesuai Syariat yang Allah turunkan kepada Nabi-Nya, mereka itulah orang-orang yang fasiq, durhaka kepada Allah." Thalib, Al-Qur'an Tarjamah Tafsiriyah, 134.

50 Departemen Agama RI, Al-Qur'an dan Terjemahnya, 116.
} 


\section{Kata Ulī al-Amr}

Penerjemahan uli al-amr dalam surah al-Nisā' [4]: 59 versi $A l$ Qur'an Tarjamah Tafsiriyah yang tertulis "para pemimpin yang menegakean syariat Islam dari golongan kalian", menunjukkan strategi transposisi dengan menghasilkan suatu perubahan makna berupa penyempitan makna pemimpin setelah diberikan sifat yang menegakekan syariat, dan mengandung unsur sosio-pragmatik, yaitu wacana kepemimpinan bagi muslim dan non-muslim, dan penegakan atau formalisasi syariat Islam. Sedangkan, penerjemahan yang dituliskan oleh Al-Qur'an Terjemah Kementerian Agama mengartikan ayat uli al-amr itu secara literal sesuai bunyi teks Arab dan struktur kalimatnya dengan strategi transferensi. ${ }^{52}$

\section{Kata Awliyā'}

Pertama, terdapat perbedaan penerjemahan antara Al-Qur'an Terjemah Tafsiriyah dengan Al-Qur'an Terjemah Kemenag terhadap kata walt dan awliya $\vec{a}$ dalam QS. al-Baqarah [2]: 257. Al-Qur'an Terjemah Tafsiriyah memberikan arti melindungi (kata kerja) untuk menerjemahkan kata wali (kata benda/ism fä́i), ${ }^{53}$ sedangkan Al-Qur'an Terjemah Kemenag menerjemahkannya dengan pelindung (kata benda/subyek). ${ }^{54}$ Yang pertama menempuh strategi transposisi, sedangkan yang kedua menempuh strategi calque. Adapun untuk kata awliyä, Al-Qur'an Terjemah Tafsiriyah menerjemahkannya dengan strategi modulasi, dari abstrak yaitu wali atau pelindung menjadi konkrit, yaitu teman. ${ }^{55}$ Sedangkan Al-Qur'an Terjemah Kemenag menerjemahkannya secara literal (calque), yaitu pelindung. ${ }^{56}$

\footnotetext{
51 "Wahai kaum mukmin, taatlah kalian kepada Allah dan taatlah kepada Rasul-Nya, serta para pemimpin yang menegakkan Syariat Islam dari golongan kalian." Thalib, Al-Qur'an Tarjamah Tafsiriyah, 103.

52 "Wahai orang-orang yang beriman! Taatilah Allah dan taatilah Rasul (Muhammad), dan Ulul Amri (pemegang kekuasaan) diantara kamu." Departemen Agama RI, Al-Qur'an dan Terjemahnya, 87.

53 "Allah senantiasa melindungi orang-orang mukmin." Thalib, Al-Qur'an Tarjamah Tafsiriyah, 51.

54 "Allah Pelindung orang yang beriman." Departemen Agama RI, Al-Qur'an dan Terjemahnya, 43.

55 "Adapun yang menjadi teman bagi orang-orang kafir adalah setan." Thalib, $\mathrm{Al}$ Qur'an Tarjamah Tafsiriyah, 51.

56 "Dan orang-orang kafir, pelindung-pelindungnya adalah setan." Departemen Agama RI, Al-Qur'an dan Terjemahnya, 43.
} 
Kedua, kata awliy $\bar{a}$ dalam QS. al-Mumtahanahah [60]: 1, diterjemahkan dalam Al-Qur'an Terjemah Tafsiriyah dan Al-Qur'an Terjemah Kemenag dengan penerjemahan yang sama, yaitu teman-teman setia. ${ }^{57}$ Oleh karenanya, keduanya sama-sama menggunakan strategi modulasi, karena mengkonkritkan makna dari makna dasar yang abstrak.

Ketiga, ada perbedaan penerjemahan antara Al-Qur'an Terjemah Tafsiriyah dengan Al-Qur'an Terjemah Kemenag terhadap kata awliyä' dalam QS. al-Nisāa [4]: 144. Al-Qur'an Terjemah Tafsiriyah menerjemahkannya dengan strategi modulasi, dari yang abstrak yaitu penolong/pelindung menjadi konkrit, yaitu pemimpin). ${ }^{58}$ Sedangkan Al-Qur'an Terjemah Kemenag menerjemahkannya secara literal (calque), yaitu wali atau pelindung atau penolong, dan sekaligus menggunakan strategi modulasi, yaitu teman yang akrab. ${ }^{59}$

Keempat, kata awliy à pada QS. al-Anfāl [8]: 73, diterjemahkan oleh Al-Qur'an Terjemah Tafsiriyah dengan saling tolong menolong. ${ }^{60}$ Oleh karenanya, ia bisa dikatakan menggunakan strategi tranposisi, karena mengubah makna nomina subjektif (ism fä́il) menjadi verba. Sedangkan Al-Qur'an Terjemah Kemenag menerjemahkannya secara literal (calque), yaitu pelindung. ${ }^{61}$

Kelima, kata awliy $\bar{a}$ ' dalam QS. al-Tawbah [9]: 71, diterjemahkan oleh Al-Qur'an Terjemah Tafsiriyah dan Al-Qur'an Terjemah Kemenag dengan arti yang sama, yaitu penolong. ${ }^{62}$ Oleh karena itu, keduanya menerjemahkannya secara literal (calque).

57 "Wahai orang-orang yang beriman, janganlah kalian jadikan musuh-Ku dan musuh kalian sebagai teman-teman setia kalian," Thalib, Al-Qur'an Tarjamah Tafsiriyah, 707; dan "Wahai orang-orang yang beriman, janganlah kamu menjadikan musuh-Ku dan musuhmu sebagai teman-teman setia.” Departemen Agama RI, AlQur'an dan Terjemahnya, 549.

58 "Wahai kaum mukmin, janganlah kalian menjadikan selain orang mukmin sebagai pemimpin kalian." Thalib, Al-Qur'an Tarjamah Tafsiriyah, 118.

59 "Wahai orang-orang yang beriman! Janganlah kamu menjadikan orang-orang kafir menjadi pemimpin selain dari orang-orang mukmin." Departemen Agama RI, AlQur'an dan Terjemahnya, 101.

60 "Orang-orang kafir satu dengan yang lainnya saling tolong menolong." Thalib, Al-Qur'an Tarjamah Tafsiriyah, 219.

${ }^{61}$ "Dan orang-orang yang kafir, sebagian mereka melindungi sebagian yang lain." Departemen Agama RI, Al-Qur'an dan Terjemahnya, 186.

62 "Kaum mukmin laki-laki dan perempuan, sebagian mereka menjadi penolong bagi sebagian yang lain." Thalib, Al-Qur'an Tarjamah Tafsiriyah, 232; dan "Dan orangorang yang beriman, laki-laki dan perempuan, sebagian mereka menjadi penolong bagi sebagian yang lain.” Departemen Agama RI, Al-Qur'an dan Terjemahnya, 198. 


\section{Analisis Sosio-Pragmatik Al-Qur'an Tarjamah Tafsiriyah Melalui Wacana Relasi Agama dan Negara dalam Konteks Demokrasi Indonesia}

Al-Qur'an Tarjamah Tafsiriyab yang ditulis oleh Muhammad Thalib hadir sebagai bentuk dinamika penerjemahan Alquran di Indonesia, sekaligus sebagai kritik dan koreksi terhadap Al-Qur'an Tarjamah Kementerian Agama RI. Tujuan kritik dan koreksi itu, menjadikan AlQur'an Tarjamah Tafsiriyah berbeda dengan Al-Qur'an Tarjamah Kementerian Agama. Perbedaan itu, selain teramati dari aspek metode penerjemahan yang digunakan, yaitu antara tafsiriyah dan harfiyah, juga meliputi aspek strategi penerjemahan.

Perbedaan metode dan strategi penerjemahan memberikan implikasi pada arti sebuah kata yang dipilih dan ditampilkan dalam menerjemahkan susunan ayat-ayat Alquran. Arti yang diekspresikan dalam bahasa Indonesia oleh penerjemahnya, yang dituliskan serta dipubilkasikan secara luas itu, kemudian berubah menjadi sebuah wacana. Karena ia telah disosialisasikan, yang kemudian dibaca dan direspon oleh pembacanya.

Dalam ayat-ayat yang menyimpan kosa kata täghbüt, tạ̣kim, uli alamr, dan awliy $\vec{a}$, terdapat wacana yang terkandung di dalamnya, yaitu relasi agama dengan Negara dalam konteks demokrasi Indonesia. Oleh karena itu, bagian ini mengulas dan menganalisis wacana-wacana yang diproduksi oleh Muhammad Thalib dalam ruang publikasi Majelis Mujahidin Indonesia (MMI) mengenai hubungan agama dengan Negara dalam ayat-ayat dimaksud dengan yang terdapat di media-media yang mereka miliki. Wacana-wacana itu selanjutnya akan dijadikan sebagai variabel yang berfungsi untuk menjelaskan aspek sosio-pragmatik (kontekstual) arti-arti beberapa kosa kata kunci tersebut dalam Al-Qur'an Tarjamah Tafsiriyah. Analisis ini memberikan uraian tentang relevansi tarjamah tafisiryah sebagai sebuah wacana dengan wacana topik serupa yang dipublikasikan dan disosialisasikan lewat media yang berbeda.

\section{Demokrasi dan Sekularisme}

Respon masyarakat Muslim terhadap demokrasi sebagai sebuah sistem pemerintahan, secara umum, bisa dikategorikan ke dalam dua pandangan, yaitu menerima dan menolak. Pandangan yang menerima, melihat bahwa demokrasi kompatibel dengan Islam, dengan argumentasi bahwa demokrasi dibangun di atas prinsip keadilan dan 
persamaan derajat yang sejalan dengan nilai-nilai universal dalam Islam. ${ }^{63}$ Ada banyak tokoh yang termasuk dalam kelompok ini, seperti Fazlur Rahman, Al-Mawdūdī, Mashood Baderin, dan lainnya. Sementara itu, kelompok yang menolak demokrasi melihat bahwa ia adalah sistem ideologis yang lahir dari budaya Barat sehingga tidak sesuai dengan dunia Islam, bahkan menilai jika demokrasi adalah system kafir. ${ }^{64}$ Dalam konteks ini, pandangan Thalib terhadap demokrasi termasuk dalam kategori kedua.

Dalam pengamatan penulis, ada dua argumentasi penolakan Thalib terhadap demokrasi, (1) argumentasi praksis, dan (2) argumentasi teologis. Argumentasi praksis Thalib bisa diamati melalui penuturan Muhammad Thalib, yang menyebutkan bahwa demokrasi sebagai ideologi dan sistem pemerintahan, di negeri-negeri asalnya tidak memberikan kebaikan sedikitpun bagi umat manusia. Barat dengan demokrasi dan sekularisme telah menghancurkan benua Afrika, Asia, dan Amerika Latin melalui penjajahan dan penguasaan ekonomi. Sehingga kelaparan, pengangguran, penindasan, kebodohan, kekerasan, kezaliman, dan kekacauan mencekam segenap penduduk di benua-benua tersebut. ${ }^{65}$ Oleh karena alasan ini, Thalib mengkritik keras mereka yang mempropagandakan demokrasi.

"Sekalipun fakta sudah sedemikian jelas, namun kelompok orang yang mengaku beragama Islam tetapi hatinya penuh rasa benci kepada Islam, karena Islam dianggap tidak nasionalistis. Kemudian terus menerus mempropagandakan doktrin Barat yang sekularistis, dengan mengabaikan fakta kehancuran moral manusia yang ada di depan mata mereka."66

Thalib menilai bahwa saat ini, pemerintah-pemerintah di Negara Barat semakin hari semakin terpuruk pada kerusakan moral sekalipun mereka sangat berbangga diri dengan hak rakyat untuk memilih dan dipilih. Dengan demokrasi, Barat tidak bisa mengatasi narkoba, prostitusi, pengumpulan kekayaan di tangan segelintir orang yang mengakibatkan kemiskinan jutaan orang, jika memang demokrasi memberikan nilai kemuliaan kepada manusia, mengapa negara-negara demokrasi terkungkung dalam kebingungan mengatasi masalah

\footnotetext{
${ }^{63}$ John 1. Esposito dan John O. Voll, Demokrasi di negara-negara Muslim: Problem dan Prospek, terj. Rahmani Astuti (Bandung: Mizan, 1999), 27.

64 Abd. Al-Qadim Zallum, Demokrasi Sistem Kufur, terj. Umar Faruq Jakarta: Bursa Ilmu Indonesia, 2001), 10.

${ }^{65}$ Majelis Mujahidin Indonesia, Risalah Mujabidin, Edisi 37 (2015), 79.

${ }^{66}$ Ibid., 79.
} 
kejahatan remaja, merajalelanya narkoba dan kerusakan moral lainnya. ${ }^{67}$

Dalam konteks Indonesia, Muhammad Thalib mendorong umat Islam Indonesia untuk mengintrospeksi teologinya dengan mengajukan pertanyaan evaluatif bagi mereka,

"Apa alasan saya mencintai tanah air dan mengesampingkan Allah sebagai pencipta tanah air saya. Adakah tanah air saya dapat memberikan panduan hidup yang benar ataukah justru saya yang harus berfikir keras untuk membuat panduan hidup bagi kelangsungan tanah air saya"68

Dengan pertanyaan reflektif di atas, Thalib berharap masyarakat Muslim Indonesia yang gegap gempita menyambut ideologi ini bisa tersadarkan dan menolak demokrasi sebagai sistem negara Indonesia. Karena baginya demokrasi secara praksis tidak memberikan perubahan kehidupan manusia menjadi lebih baik, dan justru telah menjadikan manusia di belahan dunia tertentu menjadi semakin menderita.

Sementara itu, argumentasi teologis Muhammad Thalib dalam pandangannya yang menolak demokrasi dibangun di atas legitimasi QS. al-Nūr [24]: 39 beserta penafsiran yang ia berikan kepadanya, lewat tulisannya yang bertajuk "Mengejar Fatamorgana", sebagai berikut. $^{69}$

"Orang-orang kafir itu, semua amal kebaikan mereka sia-sia. Semua yang mereka lakukan laksana fatamorgana di sebuah lembah. Orang-orang yang kehausan menyangka bahwa fatamorgana itu adalah air. Ketika mereka mendekati tempat itu, mereka tidak mendapatkan air sedikitpun. Pada hari kiamat kelak, orang-orang kafir tidak mendapatkan pahala dari Allah sedikitpun atas amal kebaikan mereka di dunia. Di akhirat kelak, Allah akan menghitung amal setiap manusia dengan sempurna. Allah mahacepat perhitungan-Nya."

Penafsiran yang diberikan oleh Muhammad Thalib terhadap ayat di atas, bahwa ayat ini menggambarkan upaya manusia mengejar kemakmuran duniawi dengan cara-cara mengingkari dan menolak Syariat Allah. ${ }^{70}$ Kata kunci dalam penafsiran Thalib terhadap ayat ini dengan demikian adalah dunia dan Syariat Allah.

\footnotetext{
${ }^{67}$ Ibid., 80.

${ }^{68}$ Ibid.

${ }^{69}$ Ibid., 48-51.

${ }^{70}$ Ibid., 48.
} 
Secara kontekstual, Thalib membaca QS. al-Nūr [24]: 39 sebagai kritik terhadap sistem pemerintahan yang dibawakan oleh pemimpin Negara-negara muslim modern, sebagaimana yang ia ketengahkan, yaitu Soekarno di era orde lama dan Jamal Abdul Naser di Mesir, serta pemimpin negara-negara berkembang lainnya. Kritik Thalib tersebut dialamatkan kepada sistem demokrasi, ideologi sekuler, dan komunis, serta tidak digunakannya syariat Islam sebagai sistem dan ideologi negara di negara yang berpenduduk mayoritas Muslim. Baginya, realitas di dunia Muslim ini adalah penyebab ketidakberhasilan pembangunan yang dicita-citakan. Dia menyebut,

"Mereka sangat bangga dengan kemampuan intelektual mereka, sehingga apapun yang mereka inginkan hanya berdasarkan pada pikiran-pikiran sempit yang mereka rumuskan dalam programprogram pembangunan nasional atau pembangunan semesta. Sistem hidup yang dijalankan oleh pemimpin Negara-negara Muslim, seperti yang dijalankan oleh Soekarno di masa orde lama, Jamal Andul Naser di Mesir, pemimpin-pemimpin Negara berkembang lainnya dengan menjiplak konsep-konsep kaum kafir. Sekalipun Soekarno dan Jmal Abdul Naser mengaku sebagai Muslim mereka tidak sungkan mengikuti sistem hidup kaum kafir. Begitu juga Jenderal Ayyub Khan di Pakistan yang memerintah antara tahun 1960-1970 yang memiliki program pembangunan semesta bagi negaranya yang Islam, tetapi dengan menentang dan meminggirkan syariat Islam. Ternyata upaya mereka hanya menghasilkan penderitaan, kekacauan dan kemiskinan di negaranya masing-masing." ${ }^{71}$

Thalib menggarisbawahi bahwa pembangunan Negara yang berkiblat pada ideologi sekularisme yang dilakukan oleh para pemimpin di negeri-negeri Islam sebagaimana dilakukan oleh Soekarno di Indonesia, Gamal Abdel Naser di Mesir, dan Jendral Ayyub Khan di Pakistan terbukti dalam sejarah hanya merupakan upaya sia-sia dan hanya mewariskan kebobrokan hingga sekarang. Menurutnya, hal ini merupakan gambaran konkret dari apa yang Allah firmankan pada ayat QS. al-Nūr [24]: 39 di atas. Lebih lanjut, dia menyarankan,

"Oleh karena itu, pemimpin Islam harus menghentikan langkahnya mengejar fatamorgana dalam membangun kehidupan bernegara agar tidak menerika azab dari Allah, seperti yang dialami oleh para penguasan kafir di negeri-negeri mereka. Kita rakyat Indonesia telah merasakan derita ini sejak proklamasi

${ }^{71}$ Ibid., 48-49. 
kemerdekaan, akibat para pemimpin yang menempuh jalan kekafiran dalam membangun Negara". ${ }^{72}$

Argumentasi Thalib terhadap penolakannya atas demokrasi dengan menarasikan bahwa demokrasi tidak membuahkan hasil pembangunan yang baik, baik di dunia Barat maupun di dunia Muslim, seperti Soekarno di Indonesia, Gamal Abdel Naser di Mesir, dan Jendral Ayyub Khan di Pakistan, serta argumentasi teologis berupa penafsiran kontekstualnya atas QS. al-Nūr [24]: 39, mengindikasikan adanya ideologi islamisme dalam pandangan Thalib, yang menolak segala sesuatu yang berbau Barat atau yang datang dari Barat, termasuk demokrasi. ${ }^{73}$

\section{Nasakom dan Pancasila}

Berangkat dari penafsirannya terhadap firman Allah dalam QS. al-Isrā' [17]: 77, peringatan Allah kepada Nabi Muhammad ketika beliau hendak tertarik untuk menerima desakan golongan kafir Quraish agar Nabi menempuh jalan kompromi dalam membangun tata kehidupan manusia antara ketentuan yang ditetapkan oleh Allah dengan keinginan yang dikehendaki oleh masyarakat kafir, Muhammad Thalib menyatakan bahwa peringatan Allah ini bukan peringatan yang bersifat temporer bagi dan saat Nabi, tapi universal, abadi, dan tanpa kenal tempat, baik dahulu, sekarang, sampai kiamat. ${ }^{74}$

Penerimaan pimpinan teras sementara organisasi Islam baik parpol maupun ormas terhadap doktrin Nasakom (Nasionalis, Agama, dan Komunis) yang dikembangkan Presiden Soekarno dengan Orde Lama-nya, dinilai oleh Thalib sebagai contoh riil kesesuaian konteks peringatan Allah pada ayat di atas dalam konteks Indonesia pasca kemerdekaan. Menurutnya, penerimaan tersebut merupakan keanehan, karena doktrin Nasakom secara elementer disikapi oleh kaum muslim awam sebagai hal yang bertentangan seratus persen dengan Islam.

"Karena Komunis yang anti Tuhan tidak akan bertemu dengan Islam maupun agama Kristen yang beriman kepada Tuhan, walaupun Tuhan Islam berbeda dengan Tuhan Kristen. Semua alasan yang dikemukakan oleh pimpinan teras tersebut berpijak pada pemikiran menyelamatkan kekayaan organisasi dan partai,

72 Ibid., 51.

${ }^{73}$ Baca Masdar Hilmy, Islamism and Democracy in Indonesia (Singapore: Institute of Southeast Asian Studies, 2010).

${ }^{74}$ Majelis Mujahidin Indonesia, Risalab Mujabidin, Edisi Spesial (2007), 8. 
keselamatan anggota organisasi dan partai, realitas objektif masyarakat yang tidak kondusif untuk menolak doktrin Nasakom dan lain sebagainya. Mereka tanpa pernah berfikir bagaimana seharusnya mengikuti ketentuan Allah dan Rasul Nya serta praktik kehidupan Rasul dan sahabatnya ketika menghadapi tawaran golongan kafir. ${ }^{75}$

Selain Nasakom, Pancasila sebagai asas tunggal dinilai oleh Thalib sebagai sesuatu yang harus dikiritisi. Hal ini sekaligus berdasarkan peringatan Allah dalam QS. al-Isrā' [17]: 77. Secara kontekstual, pandangannya menyiratkan kritik yang dia alamatkan terhadap sistem kenegaraan di Indonesia zaman Soeharto dengan rezim Orde Barunya yang mewajibkan Pancasila sebagai asas tunggal bagi setiap parpol dan ormas yang ada di Indonesia. Menurut Thalib, hal ini sama dengan menjadikan agama-agama yang ada di Indonesia sebagai subordinasi dari Pancasila. Dia mengatakan,

"Menempatkan Pancasila di atas segala-galanya sehingga Islam pun dipaksa untuk tunduk kepada penafsiran Pancasila ala kebatinan Soeharto. Persatuan nasional, kesetiakawanan, persaudaraan sebangsa dan setanah air, kerukunan dan kedamaian masyarakat, adalah dalih baru yang menjadi slogan golongan kafir, bahkan sejak zaman namrud di masa Nabi Ibrahim. ${ }^{76}$

Thalib, mengkritik para pemimpin ormas, kiai, mubalig dan ustaz yang ikut mensosialisasikan asas tunggal Pancasila. Menurutnya, mereka berada dibawah bayang-bayang konsepsi ideologis Pancasila yang dicetuskan oleh non-Muslim. Thalib memberikan argumen pandangannya ini dengan memeberikan contoh seperti Muslim Indonesia yang harus menumbuhkan sikap pluralisme sebagaimana dalam Pancasila agar tidak terjadi pemaksaan kehendak, namun anehnya golongan non-Muslim, menurut Thalib, selalu menolak aspirasi umat Islam dan tidak pernah sedikitpun memberikan toleransi. Dia menyatakan,

"Akan tetapi, anehnya golongan kafir selalu menolak aspirasi umat Islam dan tidak pernah sedikitpun memberikan toleransinya kepada kaum muslimin untuk melaksanakan pasal 29 UUD 45 dalam perspektif umat Islam sendiri." 77

Thalib dengan kritik-kritiknya di atas, secara simpul menunjukkan posisinya yang mempermasalahkan Demokrasi Pancasila sebagai ideologi kenegaraan di era reformasi ini. Pandangan dekonstruktif

\footnotetext{
75 Ibid., 8-9.

${ }^{76}$ Ibid., 9.

77 Ibid.
} 
Thalib beserta argumentasinya terhadap demokrasi Pancasila di atas merupakan pandangan minor dari masyarakat Muslim Indonesia. Karena umumnya Muslim Indonesia, melihat demokrasi Pancasila sejalan dengan Islam, khususnya dengan konsep shürä, yang tidak lagi dinilai sebagai seruan langit namun sudah menjadi jati diri bangsa Indonesia. ${ }^{78}$

Wacana seputar Demokrasi Pancasila sebagaimana yang diungkapkan oleh Thalib di atas dipertegas oleh organisasinya, yaitu Majelis Mujahidin Indonesia (MMI). Ketua Majelis Mujahidin (MM) Irfan S Awwas menyampaikan pernyataan mengenai demokrasi dan Pancasila, yaitu:

"Demokrasi telah gagal menjalankan fungsinya. Begitu juga dengan Pancasila sebagai dasar negara, gagal memperbaiki Indonesia menjadi lebih baik. Indonesia ini diibaratkan perahu besar. Penguasa yang menggunakan perahu bernama Indonesia, kerap mengambil hak-hak rakyat. Yang dilakukan penguasa tidak untuk kepentingan rakyat, tetapi kepentingan penguasa. Perilaku penguasa tersebut karena dilandasi oleh Pancasila sebagai dasar negara, dan berpandangan negara harus steril dari pengaruh agama. Penguasa memanipulasi Pancasila sebagai dasar negara, disertai opini bahwa negara harus streril, tidak boleh bawa-bawa agama. Ini menunjukkan, pemerintah telah gagal, begitu juga DPR dan MPR. Mereka tidak punya solusi." 79

Lebih jauh, Irfan menyampaikan bahwa Pancasila sebagai dasar negara itu inkonstitusional sehingga batal demi hukum. Dia menceritakan argumentasi yang dimiliki untuk mendukung pandangannya itu telah disampaikan dalam satu gelaran nasional yang diselenggarakan oleh MMI.

"Dalam Kongres Mujahidin IV, digelar Temu Nasional dengan sejumlah pimpinan ormas Islam maupun tokoh nasional untuk membahas Syariat Islam dan Reformasi UUD 1945. MMI waktu itu mengundang semua elemen politik dan ideologis, termasuk mengundang duta besar yang ada di Indonesia, bahkan vatikan. Tema yang diusung adalah "Seabad Perjuangan Indonesia dalam Penegakan Syariat Islam” sejak Sarekat Islam 1916. Kita hanya

\footnotetext{
78 Saifullah Idris, "Islam dan Demokrasi: Respon Umat Islam Indonesia terhadap Demokrasi," dalam Al-Fikr: Jurnal Pemikiran Islam, vol. 15, no. 3 (2011), 528-541.

79 "Ustadz Irfan S Awwas: Demokrasi Gagal, Pancasila Inskonstitusional," dalam https://www.voa-islam.com/read/upclose/2013/05/11/24485/irfan-sawwasdemokrasi-gagalpancasila-inskonstitusional/. Di akses pada 9/25/2018.
} 
sebagai pelanjut saja, sebelumnya telah diperjuangkan oleh tokoh Islam di masa itu," 80

Pada kesempatan lain, melalui tulisannya berjudul "Pancasila dalam Talmud" yang dimuat oleh Majalab Gatra 19 Mei 2011, Irfan memaparkan padangannya mengenai asal-usul Pancasila dan menyatakan bahwa implementasi Pancasila sudah bermasalah sejak awal hingga saat ini.

"Implementasi Pancasila sejak awal sudah bermasalah. Rezim Orde Lama Sukarno menerapkan Pancasila berbasis sinkretisme ideologi, yang dikenal dengan Nasakom (nasionalisme, agama, komunisme). Sedang rezim Suharto mengamalkan Pancasila berbasis budaya yang memunculkan ideologi asas tunggal Pancasila. Di zaman reformasi, Pancasila membonceng liberalisme berdasarkan 4 pilar kebangsaan (Bhineka Tunggal Ika, NKRI, Pancasila, dan UUD '45)." 81

Ketua Umum MMI, Irfan S. Awwas mengungkapkan persoalan implementasi Pancasila yang tidak berjalan disebabkan oleh kaum sekuler dan kaum demokrasi yang senantiasa menghalangi agama dalam kenegaraan. Dia menyebutkan,

"Selama ini kaum sekuler senantiasa berusaha memerangi agama sebagai tatanan hidup rakyat Indonesia, padahal mereka selalu mengusung slogan bebas berbuat apa saja? Ketika berbagai kerusakan sistemik menimpa negeri ini, kaum sekuler membebankan kesalahan pada umat beragama. Sementara, ketika kaum beragama ingin berbuat bebas sesuai agamanya dihalangi. Contoh, apa yang disebut Perda bernuansa syariah ingin dihapus, padahal hasil musyawarah DPRD. Bukankah kaum demokrasi berkoar hendak menjunjung tinggi kemerdekaan individu untuk berbuat sesuai keinginannya? Orang berpoligami dicacimaki, sementara perselingkuhan, lesbian, homo dan kemungkaran lainnya dibiarkan. Logika apa yang dipakai kaum sekuler ini?’"82

\section{Tafsir ayat T⿱äghūt}

Uraian pada bagian ini didasarkan pada tulisan Muhammad Thalib selaku Amir 'Am Majelis Mujahidin Indonesia (MMI) yang

\footnotetext{
${ }^{80}$ Ibid.

${ }^{81}$ Irfan S. Awwas, "Hubungan Agama dan Negara dalam Negara Pancasila," dalam Majalab Gatra, 19 Mei 2011.

82 Ibid.
} 
dipublikasikan pada situs media online organisasi yang dia pimpin tersebut, dengan judul "Tafsir Ayat Mengingkari Taghut". 83

Kata täghüt yang terdapat dalam Alquran, seperti dalam QS. alNahl [16]: 36, diartikan oleh Thalib secara etimologis sebagai akidah dan perbuatan kemusyrikan dan menyimpang. Adapun makna terminologis kosa kata ini disebut oleh Thalib sebagai "semua akidah yang sesat, perbuatan yang menyalahi syariat Islam, simbol-simbol yang menyalahi syariat Nabi Ibrahim dan semua hukum dalam bentuk apapun yang menyalahi Syariat Allah dan rasul-Nya." ${ }^{\text {" }}$

Dalam konteks lebih khusus, Thalib memaknai țäghüt sebagai segala sesuatu yang membelokkan manusia dari beriman dan beribadah kepada Allah sehingga mereka lebih mengikuti hawa nafsunya yang membawa ke arah kesesatan. Dalam istilah yang lain, täghüt berarti mempertuhankan hawa nafsu, baik dalam tingkah laku maupun pemikiran." 85

Thalib memberikan contoh täghüt dalam tingkah laku yaitu pensakralan terhadap kuburan orang yang dinilai memiliki keramat, mengambil berkah dari tempat-tempat yang pernah didiami oleh orang-orang shalih, tirakatan dalam waktu dan tempat tertentu dengan tujuan mencari berkah, dan salat malam hari 17 Agustus untuk memperingati kemerdekaan. ${ }^{86}$

Sementara itu, täghüt dalam pemikiran meliputi faham ideologis selain Islam, seperti nasionalisme, ${ }^{87}$ materialisme, liberalisme, sekulerisme, dan seluruh isme-isme lainnya. Ide hak asasi manusia ${ }^{88}$

83 Muhammad Thalib, "Tafsir Ayat Mengingkari Taghut," dalam https://www.risalahmujahidin.com/tafsir-ayat-mengingkari-thagut/. Diakses pada 25 September 2018.

84 Ibid.

85 Ibid.

86 Ibid.

87 Merujuk pada Abu Rabi', sebenarnya konsep nasionalisme diarahkan pada dua hal, spiritual dan institusional. Secara spiritual, nasionalisme berupaya mencari kepastian akan kedaulatan negara, masa lalu dan identitas budaya. Sedangkan secara institusional, nasionalisme berusaha membangun negara dengan belajar ilmu pengetahuan Barat dan pembangunan institusi Barat. Baca: Hasan Mahfudh, "Dari Ibrahim M. Abu Rabi' tentang Problematika Studi Islam Kontemporer," dalam Millati: Journal of Islamic Studies and Humanities, vol. 1, no. 1, (2016), 29. Tampaknya, kedua arah dari nasionalisme ini ditolak oleh Thalib dan dilabeli täghüt.

88 Sejarah Hak Asasi Manusia (HAM) sebagai konsensus bersama mngalami perjalanan yang cukup Panjang. Dalam pemahaman Islam sendiri, perdebatan mengenai hubungan antara Islam dan HAM cukup beragam. Meski demikian, 
dan kesetaraan gender juga termasuk di dalam kategori täghüt karena semua itu muncul dari sumber hawa nafsu. ${ }^{89}$

Thalib juga menyebutkan bahwa selain di atas, yang termasuk ke dalam kategori täghüt adalah para pemimpin (penguasa) yang menerapkan hukum yang bertentangan dengan syariat Islam, sekalipun pemimpin tersebut beragama Islam. ${ }^{90}$ Oleh karena perintah Allah adalah agar menjauhi țäghüt, maka perintah itu memiliki arti menjauhi segala hal yang termasuk dalam kategori täghüt tersebut. Thalib menyebutkan pandangannya tentang bagaimana menyikapi tāghüt, yaitu:

"Taat sepenuhnya kepada syariat Allah baik dalam urusan aqidah maupun amaliah. Dengan demikian seorang yang mengingkari Tăghüt benar-benar tidak boleh mendekati kelompok-kelompok yang memusuhi Islam atau bersikap tidak menghormati Islam atau netral agama. Karena orang-orang yang bersikap demikian sesungguhnya adalah termasuk golongan kafir, sebagaimana Allah sebutkan dalam QS. Al-Baqarah [2]: 257.”91

\section{Hubungan Muslim dengan Non-Muslim}

Tulisan Muhammad Thalib yang berjudul "Kehinaan Mencampakkan Al-Qur'an" dalam Risalah Mujahidin, edisi 37, Juni 2015 (78-90) dan "Pemurtadan di Balik Misi FKUB" dalam Risalah Mujahidin, edisi 35, April 2015 (77-80), memberikan gambaran tentang bagaimana pandangannya terhadap wacana relasi Muslim dengan non-Muslim dalam konteks kebangsaan dan kenegaraan Indonesia.

Thalib menuangkan penilaiannya terhadap umat Islam yang berpihak kepada kelompok non-Muslim, dalam konteks apa pun, sebagai bentuk tindakan mencampakkan Alquran, yang juga dapat digolongkan sebagai praktik kemunafikan. Ia menjadikan QS. al-Nisā'

mayoritas pemikir Islam menyatakan bahwa Islam memiliki ajaran-ajaran tentang Hak Asasi Manusia, bahkan Islam lebih awal mendiskusikan sekaligus menghargaihak-hak yang melekat pada manusia. Lihat: Ahmad Mujahid, "Pandangan Mufasir Indonesia Terhadap Isu-Isu Hak Asasi Manusia," dalam Mutawatir: Jurnal Keilmuan Tafsir Hadith, vol, 9, No, 2 (2019), 198. Namun, tampaknya Thalib berada pada kubu yang berseberangan dan ia menolak rumusan-rumusan HAM ini.

${ }^{89}$ Ibid.

${ }^{90}$ Ibid.

91 Ibid. 
[4]: 149 sebagai dalil bagi penilaiannya ini. Ayat ini ia artikan sebagai berikut:

"Orang-orang munafik yaitu orang-orang yang telah menjadikan orang-orang kafir sebagai teman kepercayaan melebihi kepercayaannya kepada orang-orang mukmin. Apakah orangorang munafik ingin mendapat kejayaan bersama orang-orang kafir? Padahal semua kejayaan hanyalah milik Allah." 92

Untuk mempertegas penilaiannya itu, penerjamahan atas QS. alNisā' [4]: 149 di atas dikaitkan (munäsabah) dengan dua ayat lainnya, yaitu QS. al-Furqān [25]: 30 dan QS. al-Anbiyā' [21]: 10, yang artinya: "Rasul Allah berkata, "Wahai Tuhanku, kaumku benar-benar telah menjauhiku karena aku menyampaikan Al-Qur'an ini kepada mereka"' dan "Wahai manusia, kami benar-benar telah menurunkan Alquran kepada kalian, sebuah kitab suci yang mengajarkan cara hidup mulia bagi kalian. Tidakkah kalian mau berfikir?". ${ }^{3}$

Thalib, berdasarkan analisis munāsabah-nya terhadap ketiga ayat di atas, menjelaskan bahwa kemuliaan umat Islam terletak pada komitmennya dalam menegakkan Alquran dan konsistennya dalam menyampaikan kebenaran yang Allah telah tetapkan di dalam Alquran. Sehingga ia mengecam fakta yang terjadi di dunia Muslim sekarang, yang dalam penggambarannya: "mereka beramai-ramai mencampakkan Alquran dan mengambil jalan hidup kaum kafir sebagai gantinya dengan harapan mencapai kemuliaan berdampingan atau setara kehidupannya dengan orang kafir." "94

Thalib menyatakan bahwa mengajak kaum kafir, pada umumnya, dan Ahli Kitab, khususnya, untuk masuk Islam adalah kewajiban bagi kaum Muslim berdasarkan dalil yang tegas dari Alquran dan Sunah. Ajakan dapat dilakukan melalui dakwah secara langsung, memberi penjelasan melalui debat dengan cara yang baik, dan tidak menyembunyikan sesuatu ketentuan dari Syariat Islam terhadap mereka agar memperoleh kemantapan kepada Islam. Dapat juga dilakukan dengan menyampaikan bantahan-bantahan pada mereka melalui lisan, tulisan agar mereka dengan tegas menolak Islam atau menerima Islam. ${ }^{95}$ Pernyataan Thalib ini merupakan penafsiran yang ia berikan terhadap QS. Āli 'Imrān [3]: 64 yang diartikannya sebagaimana berikut:

\footnotetext{
92 Majelis Mujahidin Indonesia, Risalah Mujabidin, edisi 37 (2015), 78.

${ }^{93}$ Ibid.

94 Ibid., 78-79.

${ }^{9}$ Majelis Mujahidin Indonesia, Risalab Mujabidin, edisi 35 (2015), 77
} 
"Wahai Muhammad, katakanlah: 'wahai kaum Yahudi dan Nasrani, marilah kita ikuti ajaran yang benar yang ada pada agama kami dan agama kalian bahwa kita tidak akan beribadah kepada siapaun selain Allah. Kita tidak menyekutukan Allah sedikitpun, dan kita tidak akan menjadikan sesama makhluk sebagai tuhantuhan selain Allah.' Jika ternyata kaum kafir Yahudi dan Nasrani menolak ajakan itu, katakanlah kepada mereka, 'bersaksilah kalian bahwa sesungguhnya kami, kaum Muslim adalah orang-orang yang tunduk kepada Allah." 96

Atas dasar keyakinan dan argumentasi teologis di atas, Thalib berpandangan bahwa relasi Muslim dengan non-Muslim secara kontekstual, seperti berdebat, bertemu dan berbicara dengan nonMuslim guna mengikuti kemauan mereka, menghilangkan kesempuranaan Islam dan fondasi keimanan, baik melalui forum atau institusi yang sekarang dikenal dengan FKUB (Forum Kerukunan Umat Beragama) adalah kebatilan dan dilarang oleh Allah dan RasulNya. $^{97}$

Oleh karena itu, Thalib menyinggung keberadaan forum dialog antar umat beragama seperti FKUB dengan redaksi mu'äwazah: "Kita berlindung kepada Allah, agar berkenan menyelamatkan kita dari tipu daya yang berkedok seminar atau musyawarah antar umat beragama yang bertujuan persatuan atau perdamaian." 98

Thalib menilai bahwa dialog antar agama yang diserukan oleh FKUB adalah tipu muslihat untuk memurtadkan umat Islam, menghancurkan Islam, bahkan pondasinya. Ia mengajukan dalil berupa QS. al-Baqarah [2]: 217 untuk menguatkan asusmsi yang diyakininya itu. ${ }^{99}$

Selain karena kecurigaan yang dibangun di atas penafsirannya terhadap dalil teologis, pandangan Thalib yang menolak dialog antar umat beragama juga disebabkan oleh pemahamannya bahwa sebagai sebuah gerakan, dialog antar agama dianggap sebagai gerakan penyatuan kebenaran dengan kebatilan, mensinkronkan jalan Allah dengan jalan setan dalam satu wadah, yang menyiratkan seruan pada kesatuan agama atau pluralisme agama yang bertentangan dengan QS. Āli 'Imrān [3]: 85, "Siapa saja yang memilih agama selain Islam, Allah

\footnotetext{
${ }^{96}$ Ibid., 78.

97 Ibid.

${ }^{98}$ Ibid.

${ }^{9}$ Ibid.
} 
tidak akan menerima amalnya. Orang itu di akhirat kelak termasuk orang-orang yang celaka nasibnya." ${ }^{\text {"100 }}$

Bagi Thalib, seruan kerukunan beragama memiliki pengaruh buruk yang diyakininya, diantaranya ialah adanya sikap pengabaian terhadap perbedaan-perbedaan antara Islam dan kekafiran, kebenaran dan kebatilan, kebaikan dan kemungkaran, dan menghilangkan sekat yang memisahkan kaum Muslim dan kaum kafir. Sehingga tidak ada lagi apa yang disebut al-walä' dan al-barrä, jihad dan perang membela kehormatan agama Allah di muka bumi. Padahal firman Allah dalam QS. al-Tawbah [9]: 29 dan 36 menyerukan kaum Muslim untuk memerangi orang kafir. ${ }^{101}$

Muhammad Thalib menilai seruan seorang Muslim kepada kesatuan agama, sebagai pernyataan kemurtadan orang tersebut dari Islam secara terang-terangan. Karena tindakan tersebut bertentangan secara diametral dengan pokok-pokok akidah dan menunjukkan kerelaannya terhadap sikap kekafiran kepada Allah, menyangkal kebenaran Alquran dan menolak Alquran sebagai penghapus semua kitab suci sebelumnya. Sikapnya itu juga berarti menolak Islam sebagai agama yang menghapuskan semua syariat dan agama sebelumnya. Dengan alasan-alasan itu, maka seruan tersebut merupakan gagasan yang tertolak secara syariat, jelas haramnya berdasarkan hujah dari Alquran dan Sunah serta ijmak, yang menjadi dasar hukum Islam. ${ }^{102}$

Dalam kontek praksis di tengah kehidupan sosial, Thalib mengharamkan dialog antar agama dan pluralisme serta berbagai tindakan yang mendukungnya. Thalib juga mengharamkan seorang Muslim menerbitakan kitab Suci agama lain, membangun masjid, gereja dan sinagog dalam satu area, menyebut gereja, kuil, kelenteng dan tempat ibadah agama lain sebagai rumah Allah, dan menyebut orang-orang yang melakukan ritual di dalamnya telah melakukan ibadah kepada Allah. ${ }^{103}$

Pandangan Thalib yang menolak ide toleransi, pluralisme dan forum dialog antar umat beragama di atas, menurut penulis, secara kontekstual, tidak bisa dipisahkan dari konteks politik demokratis pasca reformasi yang menyediakan panggung kontestasi secara bebas bagi setiap warga negara Indonesia untuk menjadi pemimpin. Isu hak

\footnotetext{
100 Ibid.

101 Ibid., 79.

102 Ibid.

103 Ibid., 80.
} 
kepemimpinan bagi non-Muslim adalah pangkal dari pandangan Thalib yang mempersoalkan relasi Muslim dan non-Muslim di atas. Karena setiap kali pesta demokrasi hendak dimulai dan sedang berlangsung pandangan Thalib dan yang seirama dengan pandangan tersebut selalu mengemuka, begitu pula pandangan yang mengafirmasi kepemimpinan non-Muslim, ${ }^{104}$ dan melihat keniscayaan kebebasan, toleransi dan pluralisme beragama. ${ }^{105}$

\section{Analisis Sosio-Pragmatik terhadap Wacana Demokrasi Pancasila dalam Al-Qur'an Tarjamah Tafsiriyah}

Keenam ayat yang berisi tentang kata täghüt dan derivasinya diartikan oleh Thalib sebagai ajakan setan (QS. al-Zumar [39]: 17, QS. al-Baqarah [2]: 257), kesyirikan (QS. al-Nahl [16]: 36), aturan-aturan sesat (QS. al-Mā'idah [5]: 60, QS. al-Nisā’ [4]: 60), dan jalan sesat (QS. al-Nisā' [4]: 76). Arti ini berbeda dengan arti yang diberikan oleh Tarjamah Al-Qur'an Kementerian Agama, yang meneterjemahkan täghüt dalam keenam ayat tersebut dengan strategi transferensi (tetap täghüt) dan semantik (yaitu, shaytän), kecuali pada QS. al-Baqarah [2]: 257 yang diartikan secara langsung sebagai setan.

Arti tăghūt sebagaimana dalam QS. al-Māiidah [5]: 60 dan QS. alNisā' [4]: 60, yaitu aturan-aturan sesat lebih banyak dan sering digunakan dalam wacana yang dipublikasikan oleh Muhammad Thalib dan Majelis Mujahidin Indonesia, dibandingkan makna yang lainnya. Aturan-aturan sesat ini diterjemahkan secara kontekstual sebagai pemikiran atau konsep hidup atau ideologi yang menyesatkan manusia dari jalan Allah, termasuk di dalamnya yaitu demokrasi, pluralisme, sekulerisme, liberalisme, dan Pancasila sebagai konstitusi. Muhammad Thalib menguraikan perihal khilafah yang menurutnya adalah sistem pemerintahan Islam sesungguhnya, sedangkan republik adalah sistem pemerintahan sekuler. Meskipun menurutnya, pengertian harfiyah keduanya, republik artinya kembali kepada masyarakat, kbiläfah juga memiliki arti yang sama, pemerintah menggantikan rakyat, namun ide besarnya adalah menolak sistem dan aturan yang ada di Indonesia dengan mengusulkan syariat Islam sebagai penggantinya.

104 Dede Rodin, "Reinterpretasi Kontroversi Kepemimpinan Non-Muslim Dalam Alquran," dalam Mutawatir: Jurnal Keilmuan Tafsir Hadith, vol. 7, no. 1 (2017), 24-49. 105 Moh Abdul Kholiq Hasan, "Ayat-Ayat Kebebasan Beragama dalam Perspektif Nasakh: Kajian Terhadap Penafsiran Ibn Kathīr dan Rashīd Ridhā," dalam Mutawatir: Jurnal Keilmuan Tafsir Hadith, vol. 6, no. 2 (2016), 284-313. 
Kata tahkim dan derivasinya yang terdapat di 3 tempat dalam Alquran (QS. al-Mā’idah [5]: 44, 45, dan 47) diartikan oleh Thalib sebagai "menetapkan dan melaksanakan hukum sesuai syariat yang Allah turunkan kepada Nabi-Nya (ayat 44 dan 47)," dan "menetapkan qisăs, hukuman setimpal dalam perkara pembunuhan dan penganiayaan sesuai syariat yang Allah turunkan kepada Nabi-Nya (ayat 45), menunjukkan penekanan kuat kepada penerapan "syariat" sebagai konstitutsi Negara dan/atau undang-undang. Hal ini selaras dengan ideologi gerakan formalisasi syariat yang mereka lakukan, sekaligus wacana mereka untuk menolak demokrasi Pancasila sebagai kontitusi Negara dan pemilu yang dinilai sebagai bentuk pengukuhan sistem syirik, atau sistem demokrasi sekuler.

Kata uli al-amr dalam QS. al-Nisā' [4]: 59 diartikan sebagai "para pemimpin yang menegakkan syariat Islam dari golongan kalian", menunjukkan tarjamah Muhammad Thalib ini berkait kelindan dengan pandangan ideologisnya terhadap kepemimpinan nasional Indonesia yang ia nilai sudah keluar dari kriteria pemimpin sebagaimana dia maksudkan lewat tarjamahnya tersebut (uli al-amr). Secara kontekstual, Thalib membaca ayat ini sebagai kritik terhadap sistem pemerintahan yang dibawakan oleh pemimpin Negara-negara Muslim modern, sebagaimana yang ia ketengahkan yaitu Soekarno di era orde lama dan Jamal Abdul Naser di Mesir, serta pemimpin negara-negara berkembang lainnya. Kritik Thalib tersebut dialamatkan kepada sistem demokrasi, ideologi sekuler, dan komunis, serta tidak digunakannya syariat Islam sebagai sistem dan ideologi negara di negara yang berpenduduk mayoritas Muslim sebagai sebab ketidak berhasilan pembangunan yang dicita-citakan.

Kata awliy à yang dijadikan sebagai salah satu pintu masuk ke dalam persoalan relasi Muslim dengan non-Muslim dalam konteks kenegaraan, Muhammad Thalib mengartikan 5 kata awliy $\vec{a}$ dalam Alquran yang terletak di 5 ayat yang berbeda sebagai teman atau teman-teman setia (QS. al-Baqarah [2]: 257, dan QS. al-Mumtahanah [60]: 1), pemimpin (QS. al-Nisā' [4]: 144), saling tolong-menolong atau penolong (QS. al-Anfāl [8]: 73 dan QS. al-Tawbah [9]: 71). Arti yang diberikan ini jika direlevansikan dengan wacana yang diproduksinya, maka berinteraksi dengan non-Muslim dalam konteks arti di atas bisa disimpulkan sebagai salah satu tindakan yang diharamkan. Relasi Muslim dengan non-Muslim secara kontekstual dalam pandangan Thalib, lebih lanjut, dinyatakan bahwa berdebat, 
bertemu dan berbicara dengan non-Muslim guna mengikuti kemauan mereka, menghilangkan kesempuranaan Islam dan fondasi keimanan, baik melalui forum atau institusi yang sekarang dikenal dengan FKUB (Forum Kerukunan Umat Beragama) adalah kebatilan dan dilarang oleh Allah dan Rasul-Nya. Ia menolak keras ideologi toleransi, bagi Thalib, seruan kerukunan beragama memiliki pengaruh buruk yang diyakininya, diantaranya ialah adanya sikap mengabaikan terhadap perbedaan-perbedaan antara Islam dan kekafiran, kebenaran dan kebatilan, kebaikan dan kemungkaran, dan menghilangkan sekat yang memisahkan kaum Muslim dan kaum kafir. Sehingga tidak ada lagi apa yang disebut al-walä' dan al-barrä', jihad dan perang membela kehormatan agama Allah di muka bumi.

\section{Kesimpulan}

Klaim Muhammad Thalib sebagai pimpinan Majelis Mujahidin Indonesia (MMI) bahwa Al-Qur'an Tarjamah Tafsiriyah dihadirkan sebagi koreksi terhadap Al-Qur'an Tarjamah Kementerian Agama yang dinilai menjadi sumber radikalisasi justru paradoks dengan konten penerjemahan ayat-ayat seputar relasi agama dan negara dalam konteks demokrasi Pancasila di dalamnya. Karena dengan analisis sosio-pragmatik, Al-Qur'an Tarjamah Tafsiriyah yang dilegitimasi oleh wacana tafsir keagamaan yang mengiringinya ternyata berusaha menunjukkan bahwa Pancasila sebagai ideologi negara Indonesia masih belum final. Artinya, syariat Islam harus diperjuangkan untuk menggantikan Undang-undang dalam sistem konstitusi Indonesia. Narasi ini dituangkan dalam bentuk wacana tentang keniscayaan memperjuangkan formalisasi Syariat ke dalam hukum positif negara. $\mathrm{Hal}$ ini mengindikasikan kemungkinan kuat bersemayamnya ideologi kontra demokrasi Pancasila dalam Al-Qur'an Tarjamah Tafsiriyah.

\section{Daftar Pustaka}

Ahmadi, Rizqa. "Model Terjemahan Al-Qur'an Tafsiriyah Ustad Muhammad Thalib." Center of Middle Eastern Studies: Jurnal Studi Timur Tengah. vol. 8, no. 1 (2015).

Awwas, Irfan S. "Apologi Tim Terjemah Al-Qur'an Kemenag." Muhammad Thalib. Al-Qur'an Tarjamah Tafsiriyah: Memahami Makna Al-Qur'an Lebih Mudah, Tepat dan Mencerabkan. Yogyakarta: Ma’had An-Nabawy, 2011. 
"Menyoal Polemik Terjemahan Al-Qur'an." Muhammad Thalib. Al-Qur'an Tarjamah Tafsiriyah: Memahami Makna Al-Qur'an Lebih Mudah, Tepat dan Mencerabkan. Yogyakarta: Ma'had AnNabawy, 2011.

Bāqī (al), Muḥammad Fu'ād 'Abd. Mu'jam Mufahras li Alfāà, Al-Qur'ān. Beirut: Dār al-Fikr, 1992.

Canale, Michael. "From Communicative Competence to Communicative Language Pedagogy." Richard, Jack C. dan Schmidt E. (eds). Language and Communication. London: Longman, 1983.

Choliludin. The Technique of Making Idiomatic Translation. Jakarta: Kesaint Blanc, 2013.

Departemen Agama RI. Al-Qur'an dan Terjemahnya. Bandung: CV. Penerbit Diponegoro, 2008.

Ek, JA.Van dan J. L. M. Trim. Threshold 1990. Cambridge: Cambridge University Press. 1991.

Esposito, John 1. dan John O. Voll. Demokrasi di negara-negara Muslim: Problem dan Prospek. Terj. Rahmani Astuti. Bandung: Mizan, 1999.

Fadil, Marjan. "Nalar Eksklusif Penafsiran Al-Qur'an Studi Terjemah Depag dan Tarjamah Tafsiriyah." Journal of Qur'an and Hadith Studies. vol. 5, no. 2 (2016).

Hanafi, Muchlis M. "Problematika Terjemahan Al-Quran." Subuf Jurnal Pengkajian Al-Qur'an dan Budaya. vol. 4, no. 2 (2011).

Hasan, Muhammad Abdul Kholiq. "Ayat-Ayat Kebebasan Beragama Dalam Perspektif Nasakh: Kajian Terhadap Penafsiran Ibn Kathîr Dan Rashîd Ridâ." Mutawatir: Jurnal Keilmuan Tafsir Hadith, vol. 6, no. 2 (2016).

Hilmy, Masdar. Islamism and Democracy in Indonesia. Singapore: Institute of Southeast Asian Studies, 2010.

Ichwan, Moch. Nur. "Negara, Kitab Suci, dan Politik: Terjemahan Resmi al-Qur'an di Indonesia." Henri Chambert-Loir (ed.). Sadur: Sejarah Terjemahan di Indonesia dan Malaysia. Jakarta: Kepustakaan Populer Gramedia, Ecole francaise d'Extreme-Orient, Pusat Bahasa, Universitas Padjadjaran, 2009.

Idris, Saifullah. "Islam dan Demokrasi: Respon Umat Islam Indonesia terhadap Demokrasi”. Al-Fikr: Jurnal Pemikiran Islam. vol. 15, no. 3 (2011), 528-541.

Indonesia, Majlis Mujahidin, Panduan Daurah Syar'iyah untuk Penegakan Syari'ah Islam. Yogyakarta: Markaz Majlis Mujahidin Pusat, 2010. 
Larson, Mildred L. Meaning Based Translation: A guide to Cross Language Equivalence. USA : University Press of America, 1998.

Levinson, Stephent C. Pragmatics. Cambridge: Cambridge Univercity Press, 1983.

Mahfudh, Hasan. 'Dari Ibrahim M. Abu Rabi' tentang Problematika Studi Islam Kontemporer." Millati: Journal of Islamic Studies and Humanities. vol. 1, no. 1 (2016).

Manzūr (ibn), Muhạmmad. Lisān al-'Arab. Kairo: Dār Mișrīyah li alTa'liff wa al-Tarjamah, 1982.

Mujahid, Ahmad. "Pandangan Mufasir Indonesia Terhadap Isu-Isu Hak Asasi Manusia." Mutawatir: Jurnal Keilmuan Tafsir Hadith, vol. 9, no. 2 (2019).

Newmark, Peter. A Text Book of Translation. Great Britain: Prentice Hall inc., 1988.

Nida, Eugene Albert. Context In Translating. Netherland: John Benjamins, 2001.

Rodin, Dede. "Reinterpretasi Kontroversi Kepemimpinan NonMuslim dalam Alquran." Mutawatir: Jurnal Keilmuan Tafsir Hadith. vol. 7, no. 1 (2017).

Tabarī (al), Abū Ja'far Muḥammad b. Jarīr b. Yazīd b. Kathīr b. Ghālib. Jämi al-Bayān fì Ta'mūl al-Qur'ān. Beirut: Dār al-Kitāb, 1992.

Thalib, Muhammad. "Beda Tarjamah Memunculkan Masalah." Muhammad Thalib. Al-Qur'an Tarjamah Tafsiriyab: Memahami Makna Al-Qur'an Lebih Mudah, Tepat dan Mencerabkan. Yogyakarta: Ma’had An-Nabawy, 2011. . "Tarjamah Harfiyah Mengundang Masalah." Muhammad Thalib. Al-Qur'an Tarjamah Tafsiriyab: Memabami Makna Al-Qur'an Lebih Mudah, Tepat dan Mencerabkan. Yogyakarta: Ma'had AnNabawy, 2011.

- Al-Qur'an Tarjamah Tafsiriyah: Memahami Makna Al-Qur'an

Lebih Mudah, Tepat dan Mencerabkan. Yogyakarta: Ma'had AnNabawy, 2011.

Koreksi Tarjamah Harfiyah Al-Qur'an Kemenag RI: Tinjauan Aqidah, Syar'iyah, Mu'amalah, Iqtishadiyah. Yogyakarta: Yayasan Islam Ahlu Shuffah \& Pusat Studi Islam an-Nabawi, 2011.

Thomas, Jenny. "Cross Cultural Failure." Applied Linguistics. vol. 4, no. 2 (1983). 
Zallum, Abd. Al-Qadim. Demokrasi Sistem Kufur. Terj. Umar Faruq. Jakarta: Bursa Ilmu Indonesia, 2001.

\section{Website}

Thalib, Muhammad. "Tafsir Ayat Mengingkari Ṭāghūt." https://www.risalahmujahidin.com/tafsir-ayat-mengingkariṬāghūt.

Awwas, Irfan S. "Demokrasi Gagal, Pancasila Inskonstitusional," dalamhttps://www.voaislam.com/read/upclose/2013/05/11/24485/irfan-sawwasdemokrasi-gagalpancasila-inskonstitusional/.

\section{Majalah}

Irfan S. Awwas, "Hubungan Agama dan Negara dalam Negara Pancasila", Majalah Gatra, 19 Mei 2011.

Majelis Mujahidin Indonesia, Risalah Mujabidin, Edisi Spesial, 2007. Majelis Mujahidin Indonesia, Risalah Mujabidin, edisi 37, Juni 2015. Majelis Mujahidin Indonesia, Risalah Mujabidin, edisi 35, April 2015. 